\title{
Sequence of the $\boldsymbol{N}$-Terminal Half of Bacillus amyloliquefaciens $\alpha$-Amylase
}

\author{
Hyangsook CHUNG and Felix FRIEDBERG \\ Department of Biochemistry, Howard University Medical School, Washington, DC 20059, U.S.A.
}

(Received 3 July 1979)

\begin{abstract}
Bacillus amyloliquefaciens $\alpha$-amylase (1,4- $\alpha$-D-glucan glucanohydrolase. EC 3.2.1.1), which is commercially supplied as 'Bacillus subtilis $\alpha$-amylase' does not cross-react immunologically with $B$. subtilis $\alpha$-amylase. This enzyme (from $B$. amyloliquefaciens) was cleaved by treatment with $\mathrm{CNBr}$ into seven fragments. Peptide A was selected for sequence determination. It is the longest one, containing 185 amino acids (i.e. approx. $50 \%$ of the total molecule) and connects to the hexapeptide of the $N$-terminus. Its primary structure was aligned by use of various proteolytic enzymes. The sequence of amino acids $181-184$ is identical with that of amino acids $14-17$ of the $\alpha$-amylase isolated from $B$. subtilis (except that amino acid 183 is asparagine rather than aspartic acid).
\end{abstract}

Bacillus subtilis produces two types of $\alpha$ amylase [1,4- $\alpha$-D-glucan glucanohydrolase, EC 3.2.1.1 (liquefying and saccharifying)] (Fukumoto \& Okada, 1963). Although the organism producing the liquefying enzyme has been reclassified as Bacillus amyloliquefaciens (Welker \& Campbell, 1967), the term ' $\boldsymbol{B}$. subtilis $\boldsymbol{\alpha}$-amylase' has been retained in many publications. Mäntsälä \& Zalkin (1979) found that purified $B$. subtilis $\alpha$-amylase (from strain YY88) has a mol.wt. of 67000 and the terminal sequence: Leu-Thr-Ala-Pro-Ser-Ile-Lys-(Ser)-Gly(Thr)-Ile-Leu-X-Ala-Trp-Asn-Trp. When tested immunologically, this enzyme cross-reacts with $\alpha$-amylase from several other strains of $B$. subtilis, but not with that of $B$. amyloliquefaciens. We have initiated structural studies on an enzyme supplied commercially as a product of $B$. subtilis (Sigma A6380). Its mol.wt. is 50000 (Detera \& Friedberg, $1979)$ and its $N$-terminal sequence, which we report here, differs completely from that noted by Mäntsälä \& Zalkin (1979).

We also isolated $\alpha$-amylase secreted into the medium by $B$. amyloliquefaciens $\mathrm{N}$ (A.T.C.C. 23845) (mol.wt. 50000). Its $N$-terminal sequence begins like that of the commercial preparation described below and these two enzymes cross-react immunologically. Thus the commercial material should be labelled 'produced by $B$. amyloliquefaciens' rather than as ' $B$. subtilis $\alpha$-amylase'.

\section{Experimental}

\section{Materials}

A culture of $B$. amyloliquefaciens $\mathrm{N}$ was made available by the American Type Culture Collection
(A.T.C.C.). Four-times crystallized B. subtilis $\alpha$ amylase was obtained from Sigma. 1-Chloro-4phenyl-3-L-tosylamidobutan-2-one ('TPCK')-treated trypsin, four-times crystallized $\alpha$-chymotrypsin and carboxypeptidase $\mathrm{Y}$ were obtained from Worthington. Staphylococcus aureus V8 proteinase was obtained from Miles Laboratories. Thermolysin and pyroglutamate aminopeptidase were purchased from Boehringer-Mannheim. All sequencing reagents (Sequanal grade) were ordered from Beckman, Pierce, or Jackson and Burdick. Polybrene was supplied by Aldrich, and $\mathrm{CNBr}$ by Pierce.

\section{Fragmentation of amylase by $\mathrm{CNBr}$}

The cleavage of methioninyl bonds by $\mathrm{CNBr}$ was performed as described by Gross \& Witkop (1962). $\alpha$-Amylase $(1 \mathrm{~g})$ was dissolved in $100 \mathrm{ml}$ of $70 \%$ $(\mathrm{v} / \mathrm{v})$ formic acid. To this solution, $\mathrm{CNBr}(1.4 \mathrm{~g})$ was added. After $20 \mathrm{~h}$ reaction at room temperature, the solution was diluted with $10 \mathrm{vol}$. of water and freezedried.

\section{Trypsin digestion limited to arginyl bonds}

The trypsin digestion was performed as described by Heil et al. (1974). Citraconylated peptide A $(100 \mathrm{mg})$ was treated with trypsin $(2 \mathrm{mg})$ in $10 \mathrm{ml}$ of $0.5 \% \mathrm{NH}_{4} \mathrm{HCO}_{3}, \mathrm{pH} 8.2$, for $4 \mathrm{~h}$ at $37^{\circ} \mathrm{C}$. Termination of the reaction was accomplished either by separation of peptides on a Sephadex G-25 column equilibrated with $0.025 \mathrm{M}-\mathrm{NH}_{3}$ and freeze-drying of the solution containing these peptides or by addition of acetic acid to a final concentration of $25 \%(\mathrm{v} / \mathrm{v})$. This solution was kept overnight to remove citra- 
conyl groups and then applied to a Sephadex G-25 column equilibrated with $25 \%$ acetic acid.

\section{Digestion with chymotrypsin}

Digestion with chymotrypsin was carried out as described above for trypsin.

\section{Cleavage with Staphylococcus aureus $V 8$ proteinase}

For enzymic cleavage of glutamyl bonds we utilized the method reported by Hogg \& Hermodson (1977). Peptide A (70 mg) was dissolved in $6 \mathrm{ml}$ of $0.05 \mathrm{M}$-acetic acid. The pH was adjusted to 4.0 with $1 \mathrm{M}-\mathrm{NaOH}$, even though the peptide precipitated at this pH. Enzyme ( $2 \mathrm{mg}$ ) was added and the suspension was incubated for $20 \mathrm{~h}$ at $37^{\circ} \mathrm{C}$.

\section{Thermolysin hydrolysis}

Hydrolysis was performed as described by Heil et al. (1974). Succinylated peptide A (130 mg) was dissolved in $13 \mathrm{ml}$ of $0.5 \% \mathrm{NH}_{4} \mathrm{HCO}_{3}, \mathrm{pH} 8.2$. Thermolysin $(2.6 \mathrm{mg})$ was added and the mixture was incubated at $55^{\circ} \mathrm{C}$ for $1 \mathrm{~h}$.

\section{Pyroglutamate aminopeptidase reaction}

Removal of pyrrolidinecarboxylic acid (5-oxoproline; pyroglutamic acid), which resulted from cyclization of glutamine, was performed as described by Podell \& Abraham (1978), by using pyroglutamate aminopeptidase. The succinylated peptide A was dissolved in $3 \mathrm{ml}$ of 'deblocking buffer' [0.1 M-sodium phosphate, $\mathrm{pH} 8.0$, containing $5 \mathrm{~mm}$ dithiothreitol, $10 \mathrm{~mm}$-EDTA (sodium salt) and 5\% (v/v) glycerol]. Pyroglutamate aminopeptidase $(1.5 \mathrm{mg})$ was added and the mixture was flushed with $\mathrm{N}_{2}$ and incubated at room temperature for $14 \mathrm{~h}$. Then the mixture was desalted on a Sephadex G-25 column and the eluant containing the peptide was freeze-dried.

\section{Modification of peptide with citraconic anhydride}

Blocking of $\alpha$-amino groups with citraconic anhydride was performed as described by Atassi \& Habeeb (1972). Peptide A (100 mg) was dissolved in $10 \mathrm{ml}$ of $0.5 \% \mathrm{NH}_{4} \mathrm{HCO}_{3}, \mathrm{pH} 8.2$, containing $6 \mathrm{M}$ guanidinium chloride. Citraconic anhydride $(0.4 \mathrm{ml})$ was added drop by drop while the $\mathrm{pH}$ was kept at 8.2 with $5 \mathrm{M}-\mathrm{NaOH}(0.7 \mathrm{ml}$ of $\mathrm{NaOH}$ was consumed). After $3 \mathrm{~h}$ reaction, salt was removed on a Sephadex G-25 column equilibrated with $0.025 \mathrm{M}-$ $\mathrm{NH}_{3}$ and the eluant containing the polypeptide was freeze-dried.

\section{Separation of peptides}

For the separation of large peptides, column chromatography with Sephadex or Bio-Gel was used. The fractions were analysed by measuring $A_{280}$.

Small peptides were separated on a column
$(1 \mathrm{~cm} \times 20 \mathrm{~cm})$ of cation-exchange-resin (Beckman spherical resin PA 35 ) by using both $\mathrm{pH}$ and concentration gradients at a flow rate of $45 \mathrm{ml} / \mathrm{h}$ at $50^{\circ} \mathrm{C}$.

Volatile pyridine/acetate buffers (Jones, 1970) were used. The initial buffer contained $250 \mathrm{ml}$ of pyridine/acetate $(0.05 \mathrm{M}$ in pyridine), $\mathrm{pH} 2.5$, or pyridine/acetate $(0.1 \mathrm{M}$ in pyridine $), \mathrm{pH} 3.5$, and the limiting buffer consisted of $250 \mathrm{ml}$ of pyridine/ acetate ( $2 \mathrm{M}$ in pyridine), $\mathrm{pH}$ 5.0. The ninhydrin reaction (Moore, 1968) was used for monitoring the elution of the peptides.

\section{Sequencing}

The peptides $(0.2-0.4 \mu \mathrm{mol})$ were sequenced by using the method of Edman \& Begg (1967) in a Beckman 890 sequencer. Both the protein/Quadrol (060275) and the peptide/ $N N$-dimethyl- $N$-allylamine ('DMAA') (111374) programs were used. Polybrene was used in conjunction with the $N N$-dimethyl$N$-allylamine program in order to prevent the premature loss of peptides from the sequencer cup (Klapper et al., 1977). When sequencing the entire peptide A fragment (with its terminal glutamine residue removed) sodium dodecyl sulphate was added to the sequencer cup as recommended for insoluble peptides (Bailey et al., 1977). Phenylthiohydantoin derivatives of the amino acids were identified by g.l.c. (Pisano et al., 1972) with a Beckman GC-65-model gas chromatograph. In addition, a t.l.c. procedure was utilized (Kulbe, 1974). Backhydrolysis of the thiazolinone derivatives of arginine and histidine was accomplished with hydroiodic acid (Smithies et al., 1971).

\section{Results and Discussion}

When $\alpha$-amylase was treated with $\mathrm{CNBr}$ and separated on a Sephadex column with $0.5 \mathrm{M}$-formic acid as eluting agent, six fragments were isolated (Fig. 1). The largest peak (peptide A) (fractions 8497), which represents the peptide connected to the hexapeptide at the $N$-terminal end of the intact enzyme, was purified further by application to a BioGel P-60 column. The amino acid composition of peptide $\mathrm{A}$ is given in Table 1. The sequence of the $N$ terminal amino acids of the intact enzyme was reported by Friedberg \& Thompson (1974) as ValAsn-Gly-Thr-Leu-Met-Gln-Tyr-Phe-Glu-Trp-Tyr. Since there appears no free amino group at the $N$ terminal end of fragment $\mathbf{A}$ as a result of cyclization of the glutamine into pyrrolidonecarboxylic acid in the process of $\mathrm{CNBr}$ treatment, this fragment was treated with pyroglutamate aminopeptidase, which removed pyrrolidonecarboxylic acid. Thus the $\alpha$ amino group of tyrosine, the penultimate amino acid at the $\mathrm{N}$-terminus of peptide $\mathrm{A}$ was freed, and this made possible further sequencing in the automated 


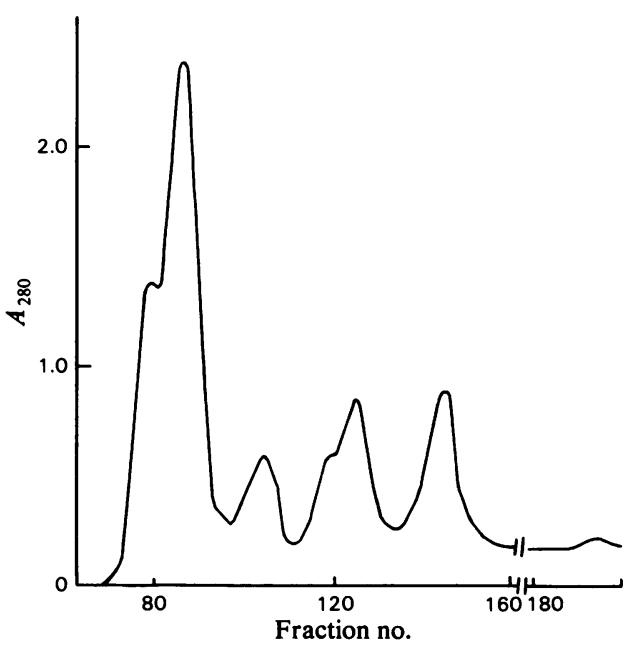

Fig. 1. Separation of a-amylase peptides obtained after CNBr treatment

The peptide mixture $(100 \mathrm{mg})$ was applied to a column $(2.5 \mathrm{~cm} \times 190 \mathrm{~cm})$ of Sephadex G-50 (fine grade), equilibrated and eluted with $0.5 \mathrm{M}$-formic acid at a flow rate of $20 \mathrm{ml} /$ hour. Fractions of $5.3 \mathrm{ml} /$ tube were collected. Fractions 84-97 were pooled as peptide $A$.

Table 1. Amino acid composition of fragment $A$ The amino acid analysis was carried out as described by Moore et al. (1958). Abbreviation used: n.d., not determined.

\begin{tabular}{|c|c|c|}
\hline \multirow[b]{2}{*}{$\begin{array}{l}\text { Amino } \\
\text { acid }\end{array}$} & \multicolumn{2}{|c|}{ Composition (residues/molecule) } \\
\hline & $\begin{array}{l}\text { From amino } \\
\text { acid analysis }\end{array}$ & $\begin{array}{c}\text { From sequence } \\
\text { data }\end{array}$ \\
\hline Asp & 26 & 28 \\
\hline Thr & 10 & 10 \\
\hline Ser & 10 & 9 \\
\hline Glu & 23 & 23 \\
\hline Pro & 6 & 6 \\
\hline Gly & 16 & 15 \\
\hline Ala & 13 & 13 \\
\hline Val & 11 & 12 \\
\hline Met & & $1^{*}$ \\
\hline Ile & 6 & 6 \\
\hline Leu & 10 & 9 \\
\hline Tyr & 11 & 11 \\
\hline Phe & 9 & 8 \\
\hline His & 6 & 5 \\
\hline Lys & 12 & 11 \\
\hline Arg & 10 & 10 \\
\hline Trp & n.d. & 8 \\
\hline Total & 179 & 185 \\
\hline
\end{tabular}

sequencer. The 20-amino acid-sequence was identified as Tyr-Phe-Glu-Trp-Tyr-Thr-Pro-Asn-Asp-GlyGln-His-Trp-Lys-Arg-Ile-Gln-X-Asp-Ala.

Trypsin-digested citraconylated peptide $\mathrm{A}$ was

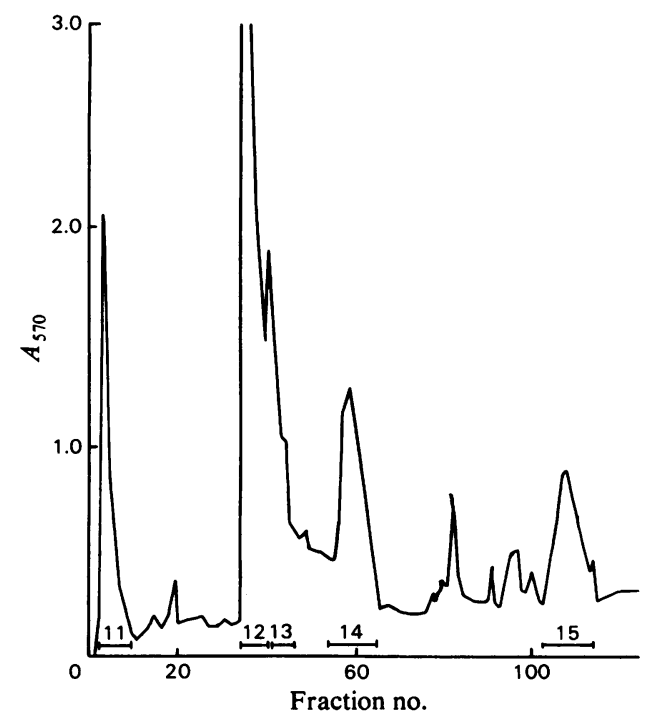

Fig. 2. Separation of peptide ACT 1 on a cation-exchange-resin column

Peptide ACT 1 (10 mg) was applied to a column $(1 \mathrm{~cm} \times 20 \mathrm{~cm})$ of Beckman PA-35 resin equilibrated with pyridine/acetate $(0.05 \mathrm{M}$ in pyridine), $\mathrm{pH} 2.5$. At fraction no. 20, a gradient starting with $250 \mathrm{ml}$ of the same buffer and with $250 \mathrm{ml}$ of pyridine/acetate $(2 \mathrm{M}$ in pyridine), $\mathrm{pH} 5.0$, as limiting buffer was begun. Fractions of $2.5 \mathrm{ml} /$ tube were collected at an elution flow rate of $45 \mathrm{ml} / \mathrm{h}$.

fractionated on a Sephadex column into fractions ACT 1, ACT 2 and ACT 3. After removal of the citraconyl group, each of these three fractions was applied to a cation-exchange-resin column. Fraction ACT 1 yielded five peptide peaks (ACT 11, 12, 13, 14 and 15) as shown in Fig. 2. Fractions ACT 14 and 15 were analysed without further purification. Fraction ACT 14 contained 17 amino acids. Its primary structure was Asn-Gln-Glu-Thr-Ser-Glu-GlnTyr-Gln-Ile-Lys-Ala-Trp-Thr-Asp-Phe-Arg (Table 2). Fraction ACT 15, which contained 18 amino acids, was sequenced as Thr-Lys-Tyr-Gly-Thr-LysSer-Glu-Leu-GIn-Asp-Ala-Ile-Gly-Ser-Leu-His-Arg (Table 2). Fraction ACT 13 was rechromatographed on a cation-exchange-resin column and two major peaks resulted. Amino acid analysis of these peptides gave identical compositions for both peptides. They contained, however, no arginine but homoserine. Thus they appeared to represent the $C$ terminus of fragment (peptide) A (Table 2). The separation of two such peptides on the ion-exchange-resin column could be due to the equilibrium state between homoserine and homoserine lactone. To quantify the terminal homoserine residue, the acid hydrolysate of one of these was exposed to $2 \mathrm{M}$ $\mathrm{NH}_{3}$ at $37^{\circ} \mathrm{C}$ for $1 \mathrm{~h}$ as described by Tang \&

Vol. 185 
Table 2. Amino acid composition of citraconylated Trypsin-digested peptides ACT 13, ACT 14 and ACT 15 The amino acid analysis was carried out as described by Moore et al. (1958). Values in parentheses indicate the number of residues obtained by sequencing. Abbreviation used: n.d., not determined.

\begin{tabular}{|c|c|c|c|c|c|}
\hline \multirow{2}{*}{$\begin{array}{c}\text { Amino } \\
\text { acid }\end{array}$} & \multirow[b]{2}{*}{ Peptide } & \multicolumn{4}{|c|}{ Composition (residues/molecule) } \\
\hline & & ACT 13 & ACT 14 & ACT 15 & Total \\
\hline Asp & & $2.2(2)$ & $2.7(2)$ & $1.0(1)$ & (5) \\
\hline Thr & & - & $1.9(2)$ & $1.3(2)$ & (4) \\
\hline Ser & & $1.0(1)$ & $1.0(1)$ & $2.0(2)$ & (4) \\
\hline Glu & & $1.9(2)$ & $5.2(5)$ & $2.0(2)$ & (9) \\
\hline Pro & & - & - & - & - \\
\hline Gly & & $1.8(2)$ & $0.7(0)$ & $1.7(2)$ & (4) \\
\hline Ala & & $0.8(1)$ & $1.4(1)$ & $1.1(1)$ & (3) \\
\hline Val & & $0.6(1)$ & - & - & (1) \\
\hline Ile & & - & $0.8(1)$ & $0.6(1)$ & (2) \\
\hline Leu & & $0.6(1)$ & - & $1.4(2)$ & (3) \\
\hline Tyr & & $1.1(1)$ & $1.1(1)$ & $0.9(1)$ & (3) \\
\hline Phe & & - & $1.0(1)$ & - & (1) \\
\hline Lys & & $1.0(1)$ & $0.9(1)$ & $2.0(2)$ & (4) \\
\hline His & & - & - & $1.2(1)$ & (1) \\
\hline Arg & & - & $1.0(1)$ & $1.0(1)$ & (2) \\
\hline Trp & & n.d. (2) & n.d. (1) & n.d. (0) & (3) \\
\hline Hse & & (1) & - & - & (1) \\
\hline Total & & $11.0(15)$ & $19.2(17)$ & $16.3(18)$ & (50) \\
\hline
\end{tabular}

Table 3. Amino acid composition of citraconylated trypsin-digested peptides ACT $12 A$ and ACT $12 B$ For further details see the legend to Table 2.

\begin{tabular}{|c|c|c|c|c|}
\hline \multirow{2}{*}{$\begin{array}{c}\text { Amino } \\
\text { acid }\end{array}$} & \multirow[b]{2}{*}{ Peptide } & \multicolumn{3}{|c|}{ Composition (residues/molecule) } \\
\hline & & $\ldots \quad$ ACT $12 \mathrm{~A}$ & ACT 12B & Total \\
\hline Asp & & $5.7(7)$ & $7.8(8)$ & (15) \\
\hline Thr & & $1.3(2)$ & $1.8(2)$ & (4) \\
\hline Ser & & - & $2.6(3)$ & (3) \\
\hline Glu & & $2.2(3)$ & $6.0(6)$ & (9) \\
\hline Pro & & $0.5(1)$ & $1.7(3)$ & (4) \\
\hline Gly & & $1.6(2)$ & $5.9(5)$ & (7) \\
\hline Ala & & $4.8(5)$ & $4.0(3)$ & (8) \\
\hline Val & & $5.1(7)$ & $2.5(2)$ & (9) \\
\hline Ile & & - & $2.5(3)$ & (3) \\
\hline Leu & & $0.8(1)$ & $4.7(5)$ & (6) \\
\hline Tyr & & $0.4(1)$ & $3.4(4)$ & (5) \\
\hline Phe & & - & $1.0(1)$ & (1) \\
\hline Lys & & $0.6(1)$ & $1.9(2)$ & (3) \\
\hline His & & $0.5(1)$ & $0.9(1)$ & (2) \\
\hline Arg & & $1.0(1)$ & $1.0(1)$ & (2) \\
\hline Trp & & n.d. (0) & n.d. (1) & (1) \\
\hline Total & & (32) & (50) & (82) \\
\hline
\end{tabular}

Hartley (1967), dried in vacuo and the diluting buffer for amino acid analysis was added just before application to the analyser. (The column in the analyser had been equilibrated with a buffer of $\mathrm{pH} 3.2$ instead of $\mathrm{pH}$ 3.25.) Amino acid analysis gave the following composition (residues/peptide): aspartic acid, 2; serine, 1; glutamic acid, 2; glycine, 2; alanine, 1 ; valine, 1 ; leucine, 1 ; tyrosine, 1 ; lysine, 1 ; and homoserine (Hse), 0.3. This peptide was analysed in the sequencer as Gly-Glu-Gly-Lys-Ala-Trp-Asp-
Trp-Gin-Val. The rest of the peptide could not be identified by this approach. Hence, carboxypeptidase $\mathrm{Y}$ digestion of fragment $\mathrm{A}$ was attempted by using the procedure suggested by Martin et al. (1977). Six amino acids having the sequence HseLeu-Tyr-Ser-Asp-Val were released in tandem by treatment with carboxypeptidase $Y$, when samples were examined 5 or $30 \mathrm{~min}$ after the beginning of incubation. Thus information on the primary structure of peptide ACT 13 was complete. 


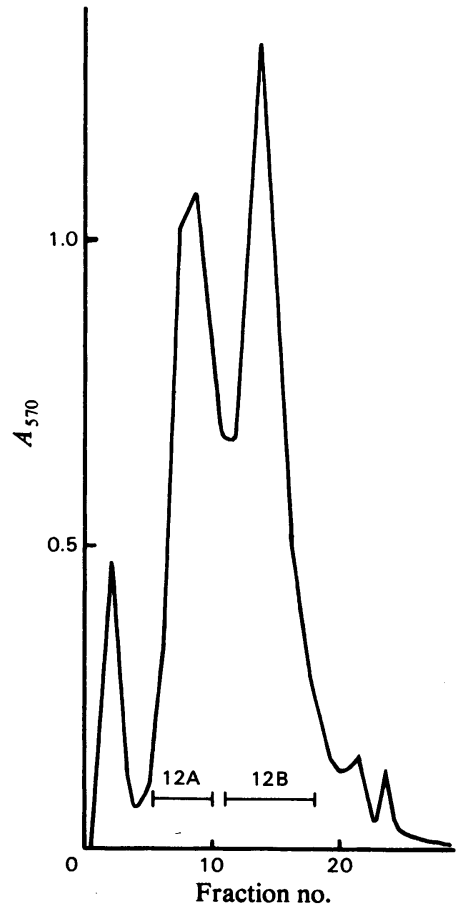

Fig. 3. Separation of peptide ACT 12 on a cationexchange-resin column

Peptide ACT 12 was applied to a column equilibrated with pyridine/acetate $(0.1 \mathrm{M}$ in pyridine), $\mathrm{pH} 3.5$, and eluted with a gradient composed of $250 \mathrm{ml}$ of the same buffer and $250 \mathrm{ml}$ of pyridine/ acetate ( $2 \mathrm{M}$ in pyridine), $\mathrm{pH}$ 5.0.
When fraction ACT 12 was separated on an ionexchange-resin column, two peptides, ACT 12A and 12B, were obtained (Fig. 3 and Table 3). The sequence of peptide ACT $12 \mathrm{~A}$ began with Asn-ValGln-Val-Tyr- and that of peptide ACT 12B (contaminated with peptide ACT 12A) was analysed as Ile-Gin-Asn-Asp-Ala-Glu. Fraction ACT 12 was exposed again to trypsin digestion (this time without prior citraconylation) to yield peptides ACT 1203, 1214, 1236 and 1283 (Fig. 4). Analysis of peptide ACT 1214 (see Table 4) indicates that this peptide is the $N$-terminal portion of peptide ACT $12 \mathrm{~A}$. Peptide ACT 1283 is a tetrapeptide with the

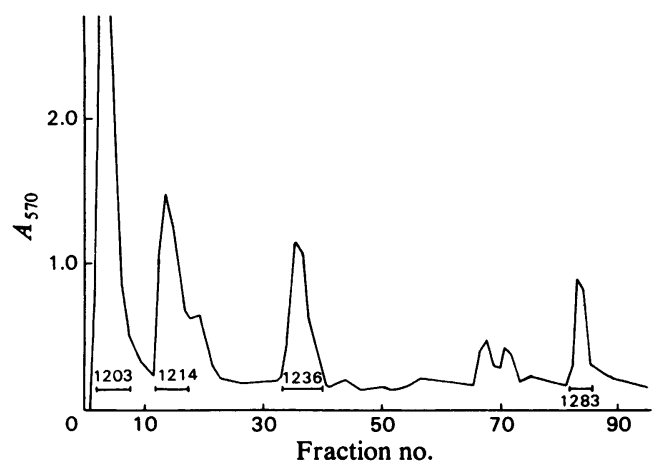

Fig. 4. Separation of trypsin-digested peptide ACT 12 Peptide mixture $(10 \mathrm{mg})$ was applied to a cationexchange-resin column $(1 \mathrm{~cm} \times 20 \mathrm{~cm})$. Details were the same as those described in Fig. 2, except that the gradient was started at the beginning of the elution.

Table 4. Amino acid composition of peptides obtained from peptide ACT 12 after digestion with trypsin For further details see the legend to Table 2.

\begin{tabular}{|c|c|c|c|c|c|}
\hline \multirow{2}{*}{$\begin{array}{l}\text { Amino } \\
\text { acid }\end{array}$} & \multirow[b]{2}{*}{ Peptide } & \multicolumn{4}{|c|}{ Composition (residues/molecule) } \\
\hline & & ACT 1214 & ACT 1236 & ACT 1283 & Total \\
\hline Asp & & $3.2(3)$ & $3.4(3)$ & - & (6) \\
\hline Thr & & 1.0 (1) & - & $1.0(1)$ & (2) \\
\hline Ser & & $1.0(1)$ & - & - & (1) \\
\hline Glu & & $2.3(2)$ & $1.3(1)$ & - & (3) \\
\hline Pro & & $1.1(2)$ & - & - & (2) \\
\hline Gly & & $1.3(1)$ & $1.2(1)$ & $1.2(1)$ & (3) \\
\hline Ala & & $3.0(3)$ & - & - & (3) \\
\hline $\mathrm{Val}$ & & 1.1 (1) & $3.4(4)$ & $1.0(1)$ & (6) \\
\hline Ile & & $2.2(3)$ & - & - & (3) \\
\hline Leu & & $1.8(2)$ & $1.0(1)$ & - & (3) \\
\hline Tyr & & $1.0(1)$ & $1.0(1)$ & - & (2) \\
\hline Phe & & - & - & - & (0) \\
\hline Lys & & $1.0(1)$ & $1.0(1)$ & - & (2) \\
\hline His & & 0.8 (1) & 0.9 (1) & - & (2) \\
\hline Arg & & - & - & $1.0(1)$ & (1) \\
\hline Trp & & n.d. (1) & n.d. (0) & n.d. (0) & (1) \\
\hline Total & & $20.8(23)$ & $13.2(13)$ & $4.2(4)$ & (40) \\
\hline
\end{tabular}


Table 5. Amino acid composition of citraconylated trypsin-digested peptides ACT 31, ACT 32, ACT 33, ACT 34 and $A C T 35$

For further details see the legend to Table 2.

\begin{tabular}{|c|c|c|c|c|c|c|c|}
\hline \multirow{2}{*}{$\begin{array}{c}\text { Amino } \\
\text { acid }\end{array}$} & \multirow[b]{2}{*}{ Peptide } & \multicolumn{5}{|c|}{ Composition (residues/molecule) } & \multirow[b]{2}{*}{ Tota } \\
\hline & & ACT 31 & ACT 32 & ACT 33 & ACT 34 & ACT 35 & \\
\hline Asp & & $1.0(1)$ & $2.2(2)$ & - & $2.5(3)$ & $2.0(2)$ & (8) \\
\hline Thr & & - & $1.0(1)$ & - & - & $1.2(1)$ & (1) \\
\hline Ser & & - & - & - & $0.7(1)$ & $1.0(1)$ & (2) \\
\hline Glu & & $1.2(1)$ & $2.7(3)$ & - & $1.3(1)$ & - & (5) \\
\hline Pro & & - & $1.0(1)$ & $0.7(1)$ & - & - & (2) \\
\hline Gly & & - & 1.1 (1) & $0.8(1)$ & $1.1(1)$ & $1.3(1)$ & (4) \\
\hline Ala & & $1.3(1)$ & - & - & $0.9(1)$ & - & (2) \\
\hline Val & & $1.9(2)$ & - & - & - & - & (2) \\
\hline Tyr & & - & $2.0(2)$ & - & $0.5(0)$ & $1.5(1)$ & (3) \\
\hline Phe & & - & $1.1(1)$ & $0.8(1)$ & $1.0(1)$ & $1.0(1)$ & (4) \\
\hline Lys & & - & $1.0(1)$ & - & - & $1.0(1)$ & (2) \\
\hline His & & - & $1.0(1)$ & - & $1.1(1)$ & $0.7(0)$ & (2) \\
\hline Arg & & $1.0(1)$ & $1.0(1)$ & $1.0(1)$ & $1.0(1)$ & $0.6(0)$ & (4) \\
\hline Try & & n.d. (1) & n.d. (2) & n.d. (0) & n.d. (1) & n.d. (0) & (4) \\
\hline Total & & $6.4(7)$ & $14.1(16)$ & $3.3(4)$ & 10.1 (11) & $10.3(8)$ & (46) \\
\hline
\end{tabular}

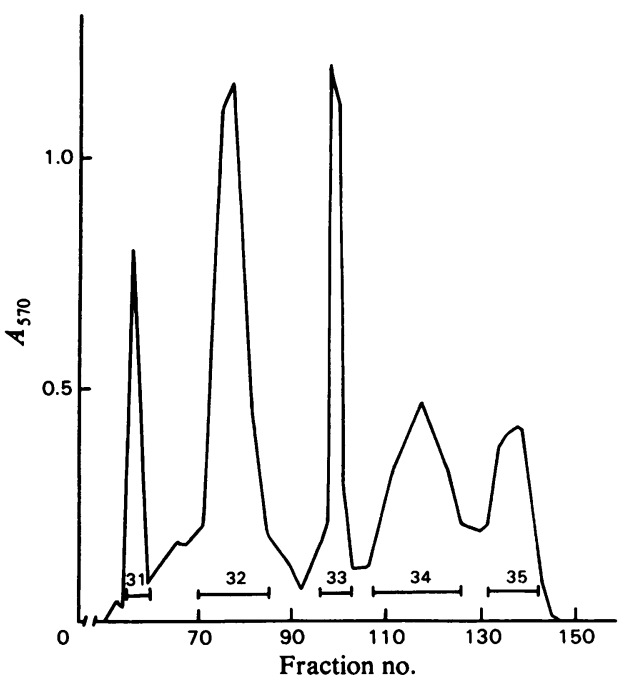

Fig. 5. Separation of peptide ACT 3 on a cation-exchange-resin column

The conditions for column development were the same as those described in Fig. 2.

sequence Gly-Thr-Val-Arg. Peptide ACT 1203 was found to be a mixture of two peptides present in different molar amounts. The peptide representing the larger portion was the arginine-containing peptide that connects to peptide ACT 1236 (see peptide ACT 12A) and contains 19 amino acids. The peptide present in smaller amounts consists of 23 amino acids and has lysine as its $C$-terminal residue.

Fraction ACT 11 was found to be a mixture of

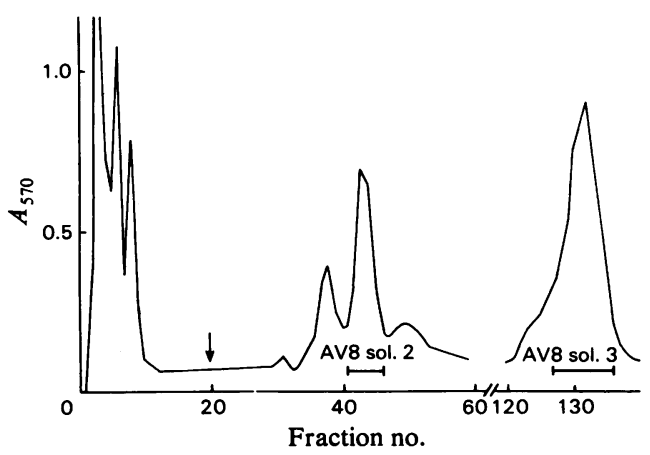

Fig. 6. Separation of the AV8 sol. fraction on a cationexchange-resin column

Approx. $5 \mathrm{mg}$ of peptide mixture was used for separation. Details were the same as those described in Fig. 2.

peptides ACT 12A and 12B. We cannot explain, however, the erratic behaviour of the ion-exchange resin towards fractions ACT 11 and ACT 12.

When fraction ACT 2 was freeze-dried, the yield was very small. The entire sample was applied to a cationic-exchange-resin column, but no distinct peptide peak was obtained after analysis.

The resolution of fraction ACT 3 by a resin column is shown in Fig. 5. The amino acid compositions of the resulting peptides are given in Table 5 . Peptide ACT 31 has the following sequence: AspTrp-Val-Gln-Ala-Val-Arg. Peptide ACT 32 has an amino acid composition identical with the first 16 amino acids of peptide $\mathrm{A}$, and its $N$-terminus is blocked. Peptide ACT 33 is a tetrapeptide with the following sequence: Phe-Pro-Gly-Arg. The amino 
Table 6. Amino acid composition of peptides $A V 8$ sol. 2 and 3

For further details see the legend to Table 2.

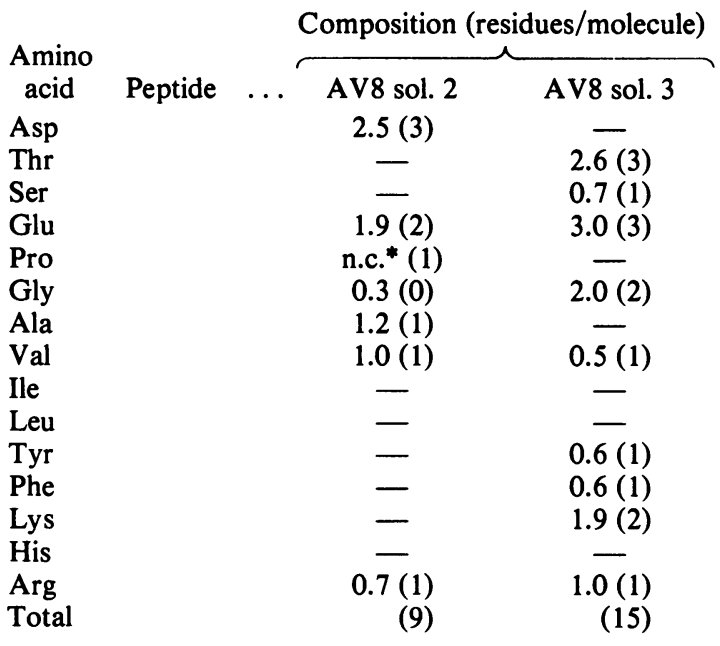

* Not calculated.

acid composition of peptide ACT 34 was identical with that of peptide $\mathrm{T} 26$, which is a peptide obtained after tryptic digestion of succinylated peptide $A$ and the sequence of which was His-Phe-Asp-GlyAla-Asp-Trp-Asp-Glu-Ser-Arg (detailed results not shown). Peptide ACT 35 was the only lysine-containing peptide that was cleaved by tryptic digestion of citraconylated peptide A, suggesting either difficult citraconylation or facile decitraconylation. Its sequence is as follows: Gly-Asn-Thr-Tyr-Ser-AspPhe-Lys.

\section{Peptides from treatment with Staphylococcus aureus $V 8$ proteinase}

After peptide A was treated with Staphylococcus aureus V8 proteinase in $0.05 \mathrm{M}$-sodium acetate, $\mathrm{pH} 4.0$, the suspension was separated by centrifugation and freeze-dried. When the buffer-insoluble fraction was dissolved in $0.5 \mathrm{M}$-formic acid and chromatographed on a column $(2.5 \mathrm{~cm} \times 190 \mathrm{~cm})$ of Sephadex G-50, five peaks were observed. The sequence of peptide AV8 insol. 55 (fractions 115$125 ; 5.3 \mathrm{ml} /$ fraction), however, was found to be: Leu-Gln-Asp-Ala-Ile-Gly-Ser-Leu-X-X-X-Asn-ValGln-Val-Tyr-Gly. This peptide contains the overlaps for peptides ACT 15 and ACT 1236. Two of the three unidentified amino acids were the histidine and arginine residues of peptide ACT 15. The third unknown amino acid $(\mathrm{X})$ can only be arginine, since the peptide ACT 1236 (i.e., the $N$-terminal portion of peptide ACT 12A) starts with Asn-Val-Gln-ValTyr-. Peptide AV8 insol. 75 was analysed without further purification. It represents a mixture of pep-

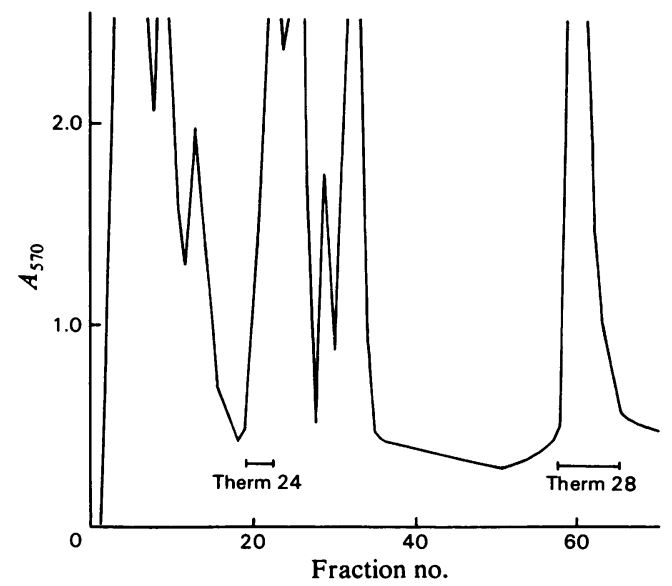

Fig. 7. Peptide Therm 2 applied to cation-exchangeresin column

Approx. $10 \mathrm{mg}$ was applied to the column. Details were the same as those described in Fig. 2.

tide AV8 insol. 55 and a peptide that begins at residue no. 27 of intact $\alpha$-amylase (Ala-Glu-HisLeu-Ser-Asp- etc.). Peptide AV8 insol. 110 (fractions 170-190) was found to have the following sequence: Gin-Tyr-Gln-Ile-Ala-Trp-Thr-Asp-PheArg-Phe-Pro-Gly-X-Gly-Asn-X-Tyr-X-Asp-PheLys. This peptide made it possible to align sequences of peptides ACT 14, ACT 33 and ACT 35. The remaining peaks were not analysed.

The buffer-soluble fraction was further separated on a cation-exchange column. Only two peaks, AV8 sol. 2 and AV8 sol. 3, were analysed (see Fig. 6 and Table 6). Peptide AV8 sol. 2 contains nine amino acids and has the following sequence: Val-Asn-ProAla-Asn-X-Asn-Gln. Val-Asn-Pro-Ala-Asn-Arg is the $C$-terminal end of peptide ACT 12A. Thus peptide ACT 12A was aligned with peptide ACT 14. Peptide AV8 sol. 3, on the other hand, sequenced as Phe-Gln-Gln-Lys-Gly-Thr-Val-X-X-Lys-Tyr-GlyThr-Lys-Ser-Glu, with two missing amino acids. By comparison with the amino acid analysis and the sequence of ACT peptides, these were found to be arginine and threonine. Thus peptide AV8 sol. 3 contains the overlaps for peptides ACT 12B and ACT 15.

\section{Thermolysin peptides}

Thermolysin hydrolysis of succinylated peptide A yielded four peaks, Therm 1, 2, 3 and 4 , on chromatography on a Sephadex G-25 column. Fraction Therm 2 was resolved further on an ion-exchange column (Fig. 7) into peptides Therm 28 and Therm 24. The former has the following sequence: Phe-ArgGly-Glu-Gly-Lys-, enabling us to attach peptide T 
33 to peptide ACT 1328. (T 33 is a peptide obtained from succinylated $A$ by digestion with trypsin.) Peptide Therm 24 contains the peptide having the sequence: Phe-Lys-Asp-Trp-. This peptide is needed to connect peptide ACT 35 to peptide ACT 31.

Fig. 8 shows the completed sequence for 191 amino acids beginning at the $N$-terminus of $\alpha$-amylase isolated from $B$. amyloliquefaciens. Note that the sequence of amino acids 181-184 of this enzyme is identical with that of amino acids 14-17 of amylase isolated from $B$. subtilis (Mäntsälä \& Zalkin, 1979) (except that residue no. 183 is asparagine rather than aspartic acid).

Val-Asn-Gly-Thr-Leu-Met-Gln-Tyr-Phe-Glu-Trp-Tyr-Thr-Pro-AsnACT 32

\section{(A/pyro)}

Asp-Gly-Gln-His-Trp-Lys-Arg-Ile-Gln-Asn-Asp-Ala-Glu-His-Leu-

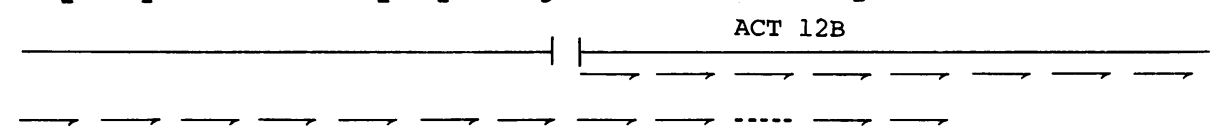

Ser-Asp-Leu-Gly-Ile-Thr-Ala-Val-Trp-Ile-Pro-Pro-Ala-Tyr-Lys-

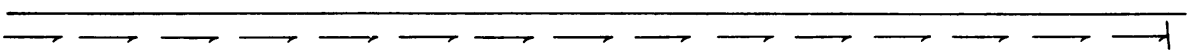

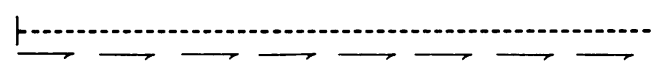

60

Gly-Leu-Asp-Gln-Ser-Asp-Asn-Ser-Tyr-Gly-Pro-Tyr-Asp-Leu-Tyr-

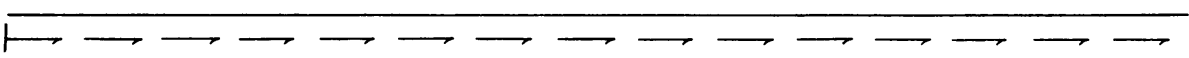

$\longrightarrow$

Asp-Leu-Gly-Glu-Phe-Gln-Gln-Lys-Gly-Thr-Val-Arg-Thr-Lys-Tyr-

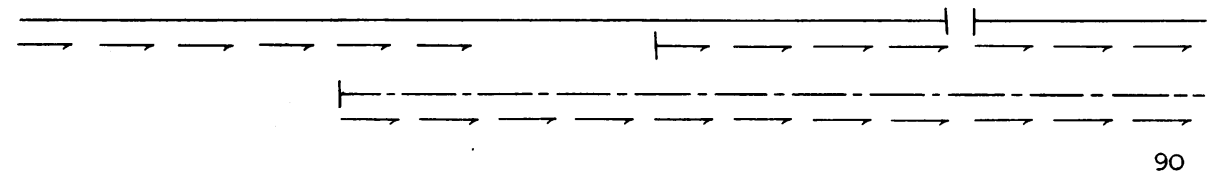

Gly-Thr-Lys-Ser-Glu-Leu-Gln-Asp-Ala-Ile-Gly-Ser-Leu-His-ArgACT 15

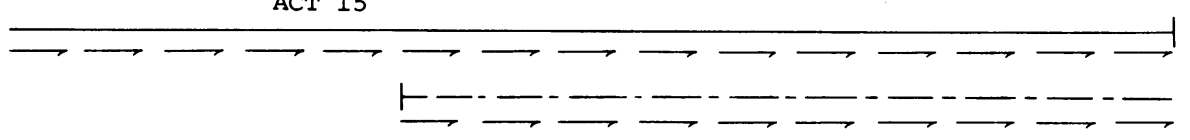

Arg-Asn-Val-Gln-Val-Tyr-Gly-Asp-Val-Val-Leu-Asn-His-Lys-AlaACT 12A

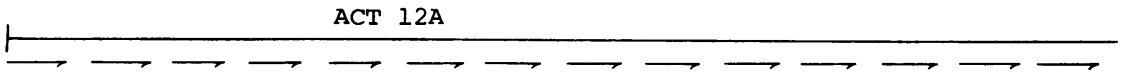

$\longrightarrow-\longrightarrow \longrightarrow \longrightarrow \longrightarrow$

Gly-Ala-Asp-Ala-Thr-Gln-Asp-Val-Thr-Ala-Val-Glu-Val-Asn-Pro-

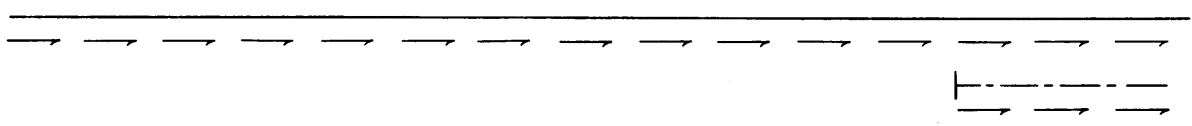


Ala-Asn-Arg-Asn-Gln-Glu-Thr-Ser-Glu-Gln-Tyr-Gln-Ile-Lys-Ala-

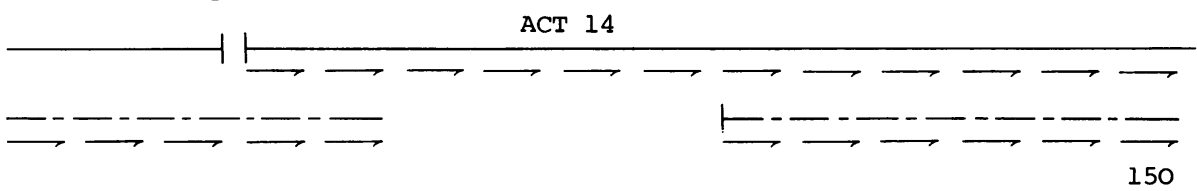

Trp-Thr-Asp-Phe-Arg-Phe-Pro-Gly-Arg-Gly-Asn-Thr-Tyr-Ser-Asp-

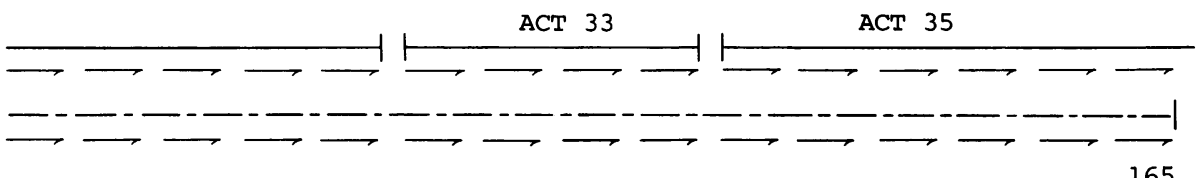

165

Phe-Lys-Asp-Trp-Val-Gln-Ala-Val-Arg-His-Phe-Asp-Gly-Ala-Asp-

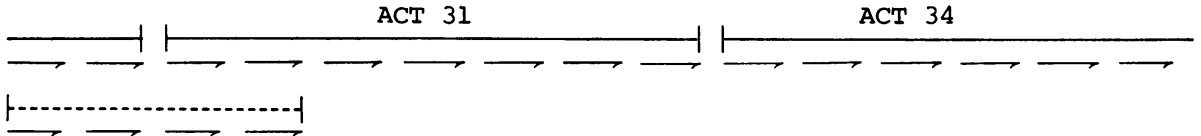

180

Trp-Asp-Glu-Ser-Arg-Lys-Ile-Phe-Lys-Phe-Arg-Gly-Glu-Gly-Lys-

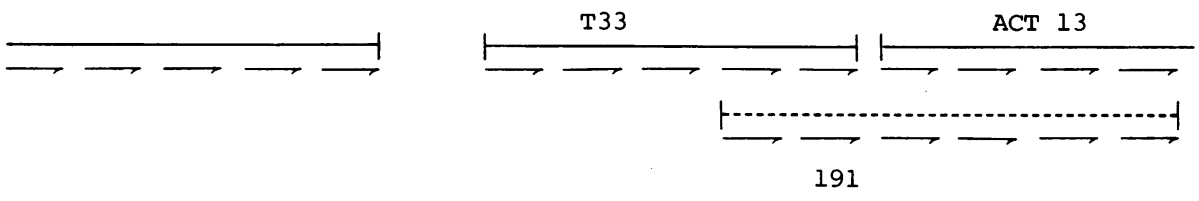

Ala-Trp-Asp-Trp-Gln-Val-Asp-Ser-Tyr-Leu-Met

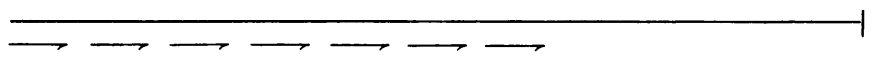

Fig. 8. Sequence of the $N$-terminal polypeptide chain of a-amylase

The sequence of residues $1-12$ has been published previously (Friedberg \& Thompson, 1974). - , peptides obtained from citraconylated or succinylated peptide $\mathbf{A}$ by trypsin digestion; .-.--, peptides from peptide $\mathbf{A}$ obtained by digestion with $S$. aureus V8 proteinase; ----, peptides from peptide A obtained by digestion with thermolysin; $\neg \neg$, sequence established with the automatic sequencer; $\_-$, sequence established by digestion with carboxypeptidase; $\cdots$, if appearing between two $\rightarrow$ symbols, indicates unidentified amino acid residue. 'A/pyro' refers to peptide $\mathrm{A}$ after treatment with pyroglutamate aminopeptidase.

\section{References}

Atassi, M. Z. \& Habeeb, A. F. S. A. (1972) Methods Enzymol. 25, 546-553

Bailey, G. S., Gillett, D., Hill, D. F. \& Petersen, G. B. (1977) J. Biol. Chem. 252, 2218-2225

Detera, S. D. \& Friedberg, F. (1979) Int. J. Peptide Protein Res. 14, 364-372

Edman, P. \& Begg, G. (1967) Eur. J. Biochem. 1, 80-91

Friedberg, F. \& Thompson, J. (1974) Acta Chem. Scand. 28, 815-816

Fukumoto, J. \& Okada, S. (1963) Ferment. Technol. 41, 427-434

Gross, E. \& Witkop, B. (1962) J. Biol. Chem. 237, 18561860

Heil, A., Mueller, G., Noda, L., Pinder, T., Schirmer, H., Schirmer, I. \& von Zabern, I. (1974) Eur. J. Biochem. 43, 131-144

Hogg, R. H. \& Hermodson, M. A. (1977) J. Biol. Chem. 252, 5135-5141

Jones, R. T. (1970) Methods Biochem. Anal. 18, 205-258
Klapper, D. G., Wilde, C. E., III \& Capra, J. D. (1977) Anal. Biochem. 85, 126-131

Kulbe, K. D. (1974) Anal. Biochem. 59, 564-573

Mäntsälä, P. \& Zalkin, H. (1979) J. Biol. Chem. 254, 8540-8547

Martin, B., Svendsen, I. \& Ottesen, M. (1977) Carlsberg Res. Commun. 42, 99-102

Moore, S. (1968) J. Biol. Chem. 243, 6281-6283

Moore, S., Spackman, D. H. \& Stein, W. H. (1958) Anal. Chem. 30, 1185-1190

Pisano, J. J., Bronzert, T. J. \& Brewer, H. B. (1972) Anal. Biochem. 45, 43-59

Podell, N. N. \& Abraham, G. N. (1978) Biochem. Biophys. Res. Commun. 81, 176-185

Smithies, O., Gibson, D., Fanning, E. M., Goodfliesh, R. M., Gilman, J. G. \& Ballantyne, D. L. (1971) Biochemistry 10, 4912-4921

Tang, J. \& Hartley, B. S. (1967) Biochem. J. 102, 593599

Welker, N. E. \& Campbell, L. L. (1967) J. Bacteriol. 94, $1124-1130$

Vol. 185 